\title{
Nest and egg description of threatened Herpsilochmus spp. from coastal forest habitats in Rio Grande do Norte, Brazil (Aves: Thamnophilidae)
}

\author{
Marcelo da Silva ${ }^{1}$; Mauro Pichorim ${ }^{1} \&$ Márcio Z. Cardoso ${ }^{1,2}$ \\ 1 Departamento de Botânica, Ecologia e Zoologia, Centro de Biociências, Universidade Federal do Rio Grande do Norte, \\ 59072-970 Natal, Rio Grande do Norte, Brasil. \\ 2 Corresponding author. E-mail:mzc@cb.ufrn.br
}

\begin{abstract}
We provide description of eggs and nest structure for two Brazilian antwrens, including the IUCN "vulnerable" species, H. pectoralis Sclater, 1857, and the BirdLife International "near-threatened", H. sellowi Whitney \& Pacheco, 2000. Our observations derive from a larger study on Herpsilochmus Cabanis, 1847 distribution in coastal forest fragments in the northern range limit of the Brazilian Atlantic rainforest. Both species nested in relatively open forest. The nest of $H$. sellowi was built with fungal hyphae, a trait common among some birds. Both eggs were moderately beige with brown spots. Most of the information on Brazilian antwren nesting comes from species that do not occur in the Atlantic rainforest. This is the first account for nest behavior for Atlantic rainforest antwrens. KEY WORDS. Herpsilochmus pectoralis; Herpsilochmus sellowi.
\end{abstract}

\begin{abstract}
RESUMO. Descrição de ninhos e ovos de espécies ameaçadas de Herpsilochmus em habitats florestais costeiros no Rio Grande do Norte, Brasil (Aves: Thamnophilidae). Descrevemos a estrutura do ninho e características dos ovos de duas espécies brasileiras de Herpsilochmus, incluindo a espécie vulnerável (IUCN) $H$. pectoralis Sclater, 1857 e a quase ameaçada (BirdLife International) H. sellowi Whitney \& Pacheco, 2000. Nossas observações derivam de um estudo maior sobre a distribuição de Herpsilochmus Cabanis, 1847 em fragmentos costeiros de Mata Atlântica em seu limite norte. Ambas as espécies nidificam em floresta relativamente aberta. $O$ ninho de H. sellowi foi construído com hifas de fungo (Marasmius), uma característica comum entre algumas aves. Os ovos das duas espécies foram moderadamente beges, com pequenas manchas marrons. A maioria das informações disponíveis sobre nidificação do gênero no Brasil provem de espécies que vivem fora da Mata Atlântica. Este é o primeiro relato do comportamento de nidificação para Herpsilochmus na Mata Atlântica.
\end{abstract}

PALAVRAS-CHAVE. Herpsilochmus pectoralis; Herpsilochmus sellowi.

Herpsilochmus Cabanis, 1847 includes 15 poorly studied species, with ten species in Brazil. Descriptions of nests and nesting behavior are available for two species, $H$. longirostris Pelzeln, 1868, from the Brazilian savanna, and $H$. dugandi Schauensee, 1945, from the Amazon Basin (STRAube et al. 1992, Marini et al. 1997, Zimmer \& Isler 2003). Here, we describe nests and egg traits of two endemic Herpsilochmus antwrens: H. pectoralis Sclater, 1857 and H. sellowi Whitney \& Pacheco, 2000. The threatened $H$. pectoralis (BirdLife InTERNATIONAL 2008a, MMA 2003) is limited to the northeastern region of Brazil, from the states of Maranhão to Rio Grande do Norte and south to Bahia (Ridgely \& Tudor 1994, Zimmer \& Isler 2003). The recently described $H$. sellowi (the Caatinga Antwren) is a near-threatened species (BirdLife InTERnATIONAL 2008b) originally thought to be restricted to the Brazilian semi-arid Caatinga (Whitney et al.
2000) but that may be common in forest fragments in coastal areas of the state of Rio Grande do Norte.

Birds and nests were observed in a mosaic of forest fragments on the coastal area of the state of Rio Grande do Norte, Brazil. The surrounding landscape is heterogeneous, but comprises mostly agricultural land. Nest description follows SIMON \& PACHECO (2005). Eggs and nests were measured with a caliper (to the nearest $0.05 \mathrm{~mm}$ ) and a small ruler $(1 \mathrm{~mm})$. Eggs were weighed on a Pesola scale (to the nearest $0.1 \mathrm{~g}$ ). Egg coloration was determined following the color guide of SMITHE (1975).

On 15 April, 2006, one nest of $H$. pectoralis was found in a forest gap of coastal woody scrub ("restinga") dominated by Myrcia aff. guianensis (Aubl.) DC., 1828, Psidium oligospermum Mart., 1828 (both Myrtaceae) and Anacardium occidentale Linnaeus, 1753 (Anacardiaceae) in the Pipa Ecological Sanctu- 

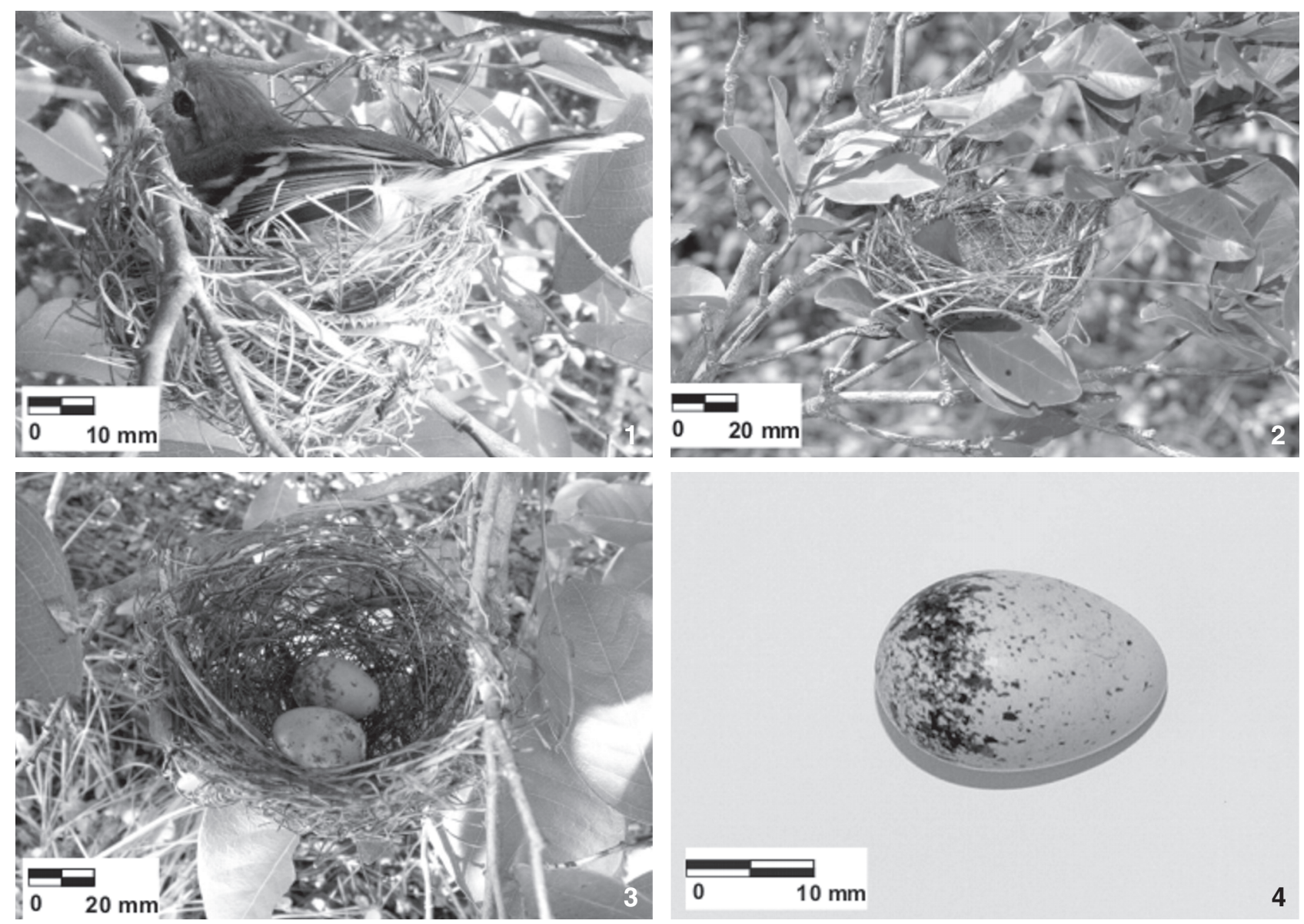

Figures 1-4. (1-2) Nests of Herpsilochmus pectoralis and $H$. sellowi, respectively; (3-4) eggs of $H$. pectoralis and $H$. sellowi, respectively. Photo credits: Bruno França and Mauro Pichorim.

ary (Tibau do Sul municipality, 06²13'46"S, 3504'08”W, $60 \mathrm{~m}$ elevation). The unlined, cup-shaped nest was in a low, horizontal fork of Maytenus impressa Reissek, 1861 (Celastraceae), $1 \mathrm{~m}$ above the ground, built mostly of grass with grass roots, passionflower tendrils, leaves of various sizes and twigs from a legume vine. Outside diameter was 71 x $67 \mathrm{~mm}$ (widest and perpendicular) and internal $51 \times 50 \mathrm{~mm}$, inside depth was 45 $\mathrm{mm}$, and total height was $60 \mathrm{~mm}$ (Fig. 1). Two eggs were in the nest being brooded by the female. The eggs (19.2 x $14.3 \mathrm{~mm}$, $\mathrm{N}=1$ ) were beige (Color 219D Beige), with brown spots mainly at the obtuse pole (Color 221A-Warm Sepia) (Fig. 2). Both male and female were seen participating in incubation, based on a four-hour observation period. Callithrix jacchus (Linnaeus, 1758) (Callitrichidae) came near the nest (but in the canopy) on one occasion and while close to the nest tree the female was agitated, constantly looking in the direction of the wandering marmosets in the canopy.

On 2 September, 2006, a nest of $H$. sellowi was discovered in a forest fragment in the municipality of Extremoz
(0541'12"S, 3541'12"W, 47 m elevation) with dominant plant species: Curatella americana Linnaeus, 1759 (Dilleniaceae), Anacardium occidentale and Hancornia speciosa Gomes, 1803 (Apocynaceae). The nest was under construction and both male and female were seen bringing nesting material and building the nest. The nest was apparently complete five days later and both sexes visited the nest without further construction. Seven days after discovery, two eggs were seen in the nest.

The nest was similar to the first (external diameter $=56 \mathrm{x}$ $50 \mathrm{~mm}$, internal $=46 \mathrm{x} 44 \mathrm{~mm}$, depth $=30 \mathrm{~mm}$, height $=40$ $\mathrm{mm}$, nest height $=3.6 \mathrm{~m}$, Fig. 3 ) and built in a tree of Byrsonima gardneriana Juss. (Malpighiaceae). This nest included mostly fungal hyphae (Marasmius sp. - Fungi: Marasmiaceae), with grass blades and sheaths, tendrils, pieces of leaves and web. The eggs (18.5 x $12.5 \mathrm{~mm}, 1.1 \mathrm{~g}, \mathrm{~N}=1$ ) were light beige (Color 92 Pale Horn) with brown spots concentrated on the obtuse pole (Color 31 Maroon, Fig. 4). Both adults were observed incubating. Again, only the female was observed turning the eggs (total observation time for this species was 17 hours).

Revista Brasileira de Zoologia 25 (3): 570-572, September, 2008 
The general shape of the nests reported here is similar to $H$. longirostris and other Thamnophilidae, including Thamnophilus Vieillot, 1816, Dysithamnus Cabanis, 1847, Taraba Lesson, 1830, Thamnomanes Cabanis, 1847, Formicivora Swainson, 1858 and some Myrmotherula Sclater, 1858 (SICK 1997, ZIMMER \& IsLER 2003). Similar to other Thamnophilid nests, nest walls are thin and the eggs can be seen through them (Roper 2003), especially in H. sellowi. Nests of other Herpsilochmus are more complex and materials tend to be more tightly intertwined. For instance, nests of $H$. dugandi contain bright green moss, with several wide stems of lichens around the bottom (ZIMMER \& IsLER 2003) and nests of $H$. longirostris are composed of several leaves (especially of the bamboo Guadua Kunth, 1822 (Poaceae), grass spadices, filaments of the fungus Marasmius, kapok and radicels (StRAube et al. 1992). The seemingly odd habit of using fungus as nest material is shared with other Thamnophilidae such as Myrmeciza ruficauda (Wied, 1831), Thamnophilus torquatus Swainson, 1825, T. atrinucha Salvin and Goodman, 1892 and Herpsilochmus longirostris. (ONIKI 1975, Straube et al. 1992, Sick 1997). The suggestion that species of this genus nest in upper levels of the vegetation (ZIMMER \& IsLER 2003) is not supported here. Perhaps the low $(1 \mathrm{~m})$ nest of $H$. pectoralis possibly avoids canopy moving Callithrix jacchus, a common species in the area.

Two egg clutch size is within the modal size for the Thamnophilidae and, while it is apparently fixed at two in most species (probably a tropical feature), Thamnophilus ruficapillus Vieillot, 1816 and T. caerulescens Vieillot, 1826 lay three eggs while Myrmornis Hermann, 1783 lays one (Zimmer \& Isler 2003).

The general biology of species in Herpsilochmus is still poorly known. Reproduction described here of $H$. sellowi in Atlantic forest shows that it is not restricted to the Caatinga. Furthermore, we have seen both species often in the coastal forests of eastern Rio Grande do Norte. Evidently the species is more widely distributed with active reproduction than was previously thought. Better understanding of distribution and reproductive biology will be needed to inform conservation measures. We hope that this study will generate further research that may also find additional occupied areas and that additional reproductive information may help determine whether populations are stable.

We thank David Hasset for permitting our research on his property and Valdenir Andrade for logistical support. Thanks also to Bruno Albuquerque who found one of the nests. Fungal material was identified by Iuri Baseia (UFRN) and plant material was identified by Rubens Queiroz (Departamento de Botânica, Unicamp), to whom we are grateful. We also thank
James Roper for reviewing the manuscript and improving our English. Partial support for this research was granted by the graduate program in Biological Sciences at the Universidade Federal do Rio Grande do Norte.

\section{LITERATURE CITED}

BirdLife International. 2008a. Species facsheet: Herpsilochmus pectoralis. Available online at: http://www.birdlife.org [18.VIII.2008].

BirdLife International. 2008b. Species factsheet: Herpsilochmus sellowi. Available online at: http://www.birdlife.org [18.VIII. 2008].

Marini, M.Â.; M.F. Pereira; G.M. Oliveira \& C. Melo. 1997. Novos registros de ninhos e ovos de três espécies de aves do Brasil Central. Ararajuba 5: 244-245.

MMA. 2003. Lista das espécies da fauna brasileira ameaçadas de extinção. Instrução Normativa $\mathbf{n}^{\circ} 3$. Brasília, Diário Oficial da República Federativa do Brasil, Ministério do Meio Ambiente, 28.V.2003.

ONIKI, Y. 1975. The behaviour and ecology of slaty antshrikes (Thamnophilus punctatus) on Barro Colorado Island, Panama Canal Zone. Anais da Academia Brasileira de Ciências 47: 477-515.

Ridgely, R.S. \& G. Tudor. 1994. The birds of South America. Austin, University of Texas Press, vol. 2, XII+814p.

Roper, J.J. 2003. Nest-sites influence nest predation differently at natural and experimental nests. Ornitologia Neotropical 14: $1-14$.

SICK, H. 1997. Ornitologia brasileira. Rio de Janeiro, Editora Nova Fronteira, 912p.

Simon, J.E. \& S. PACheco. 2005. On the standardization of nest descriptions of Neotropical birds. Revista Brasileira de Ornitologia 13: 143-154.

Smithe, F.B. 1975. Naturalist's colour guide. New York, American Museum of Natural History, 228p.

Straube, F.; M.R. Bornschein \& D.M. Teixeira. 1992. The nest of the large-billed antwren Herpsilochmus longirostris. Bulletin of the British Ornithological Club 112: 277-279.

Whitney, B.M.; J.F. Pacheco; D.R. Buzzetti \& R. Parrini. 2000. Systematic revision and biogeography of the Herpsilochmus pileatus complex, with description of a new species from northeastern Brazil. Auk 177: 869-891.

Zimmer, K.J. \& M.L. IsLer. 2003. Family Thamnophilidae (typical antbirds), p. 448-681. In: J. Del Hoyo; A. Elliot \& D.A. Christie (Eds) Handbook of the birds of the world. Barcelona, Lynx Editions, vol. 8, X+845p.

Submitted: 01.VII.2008; Accepted: 10.IX.2008.

Editorial responsibility: Kleber del Claro 